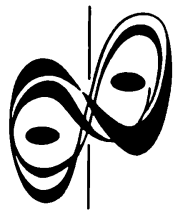

Acta Genet Med Gemellol 42: 35-39 (1993)

(C) 1993 by The Mendel Institute, Rome

Received 27 January 1993

Final 30 November 1993

\title{
Twinning Rate in the Muslim Population of West Bengal
}

\author{
A.B. Das Chaudhuri, S. Basu, S. Chakraborty \\ Human Genetics Laboratory, Department of Anthropology, University of Calcutta, India.
}

\begin{abstract}
Total birth records for the Bengalee Muslim population (BMP) and the Bengalee Hindu caste population (BHCP) for the period 1980-1988 were 17,720 and 119,107 respectively. Of these, the number of twin pairs were $363 \mathrm{BMP}$ and 1,229 BHCP. These data were obtained from the registers of the following hospitals: Islamia Hospital, NRS Medical College and Hospitals and RG Kar Medical College and Hospitals, Calcutta and Medinipore Sadar Hospital, West Bengal, India. The twinning rates found were 20.48 and 10.57 per thousand deliveries in the BMP and BHCP respectively. The proportion of twins, 0.02048 , in the BMP was significantly higher $(\mathrm{Z}=12.38, \mathrm{p} \leqslant 0.01)$ than that in the BHCP, 0.01057. This finding of a higher twinning rate in the BMP is corroborated by the fact that available data on the Muslim population of Srinagar in Kammu and Kashmir, and Lucknow and Kanpur in Uttar Pradesh show higher twinning rates than the other populations of India. This increased twinning rate may be due to the greater amount of inbreeding in the BMP.
\end{abstract}

Key words: Twinning rate, Inbreeding, Muslim population.

\section{INTRODUCTION}

Existing literature indicates that a valid explanation of the hereditary nature of twinning has not, to date, been found. However, the twinning rate among relatives of twins is, at most, slightly higher than the rate in the general population. Since the beginning of this century many investigators have considered the individual modes of inheritance related to monozygotic (MZ) and dizygotic (DZ) twinning, given that their origins are different. That the hereditary factor of twinning is of the recessive type has been advocated by many researchers $[4,5,7,8,11,13,22,25]$. The racial ddifferences in the frequency of DZ twinning may be due to genetic factors [18]. The conclusion that a singleness to twinning be ascribed to a single gemellogenetic or ' $G$ ' factor has also been made on 
the basis that both $\mathrm{MZ}$ and $\mathrm{DZ}$ twinning can occur in the same family [10]. In a study of the Jorubas in Western Nigeria, it was concluded that it is very difficult to reconcile $\mathrm{DZ}$ twinning with the theory of a genetic determinism in twinning by a single gene [19]. The possible polygenic nature of twinning was also investigated [24]. Another suggestion was that twinning in man is recessive and sex limited [3].

Based on the above, if it is assumed that the twinning phenomenon is due to the nondominance and/or homozygosity of genes then one would expect to find an increased twinning rate in a population with a high rate of consanguineous marriages rather than in one without them. Such an increase is logical since inbreeding leads to an increase in rare recessive homozygotes. We intend to examine this proposition by comparing the twinning rate of the Bengalee Muslim population (BMP), which has a high coefficient of inbreeding, with that of the Bengalee Hindu caste population (BHCP) which does not entertain this practise.

The BMP is a Bengal-speaking population, by religion faithful to Islam. Presently it constitutes approximately $25 \%$ of the total population of West Bengal. The origin of the BMP is mainly from the low caste Hindu groups [9]. The BHCP is a Bengalispeaking endogamous caste group of West Bengal and faithful to Hinduism. It consists of scheduled and non-scheduled caste groups. Ethnically, the BHCP is probably a blend of Dravidian and Mongoloid stocks with a strain of Indo-Aryan blood in the higher caste groups [21].

\section{MATERIAL AND METHODS}

Data, consisting of a total of 17,720 BMP and 119,107 BHCP births, were collected for the period 1980-1988 from Islamia Hospital, NRS Medical College and Hospitals and RG Kar Medical College and Hospitals of Calcutta and Medinipore Sadar Hospital, Medinipore district, West Bengal. Other minor ethnic communities, such as Christians, Sikhs and tribals (in the case of Medinipore Sadar Hospital) were not included in the study.

The information details taken from the hospital records of twin births were: name and address, age of mother, parity, labour history and infants' birthweights and sex. Twin births were recorded as they occurred rather than employing any selective technique. Zygosity of the twins was determined on the basis of Weinberg's Differential Rule [26].

\section{RESULTS AND DISCUSSION}

Of the joint 17,720 BMP and 119,107 BHCP births recorded in the four hospitals for the period 1980-1988, there were 363 and 1259 twins births respectively for each group (Table). The Table also shows the annual MZ, DZ and total twinning rates per 1,000 deliveries for the same period. Twinning rates found were 20.48 and 10.57 per 1,000 in the BMP and the BHCP, respectively. This finding of a higher rate in the BMP is corroborated by the fact that data available on the Muslim populations of Srinagar in Jammu and Kashmir, and Lucknow and Kanpur in Uttar Pradesh showed higher twinning 
Table - Twinning rates in the Muslim and Hindu caste populations, 1980-1988

\begin{tabular}{|c|c|c|c|c|c|c|c|c|}
\hline \multirow{3}{*}{ Year } & \multicolumn{2}{|c|}{ Total births } & \multicolumn{6}{|c|}{ Twinning rate per 1,000 deliveries } \\
\hline & \multirow[t]{2}{*}{ Muslim } & \multirow[t]{2}{*}{ Hindu } & \multicolumn{2}{|c|}{ Total } & \multicolumn{2}{|c|}{ MZ } & \multicolumn{2}{|c|}{ DZ } \\
\hline & & & Muslim & Hindu & Muslim & Hindu & Muslim & Hindu \\
\hline 1980 & 1373 & 12469 & 20.39 & 9.86 & 11.65 & 4.25 & 8.74 & 5.61 \\
\hline 1981 & 1950 & 12836 & 13.84 & 10.83 & 5.64 & 3.66 & 8.20 & 7.17 \\
\hline 1982 & 1088 & 13358 & 20.22 & 11.83 & 12.86 & 5.68 & 7.35 & 6.14 \\
\hline 1983 & 1663 & 12444 & 29.46 & 10.85 & 17.44 & 5.38 & 12.02 & 5.46 \\
\hline 1984 & 1970 & 13256 & 21.82 & 10.26 & 10.66 & 2.72 & 11.17 & 7.54 \\
\hline 1985 & 2171 & 13663 & 26.25 & 10.10 & 12.44 & 3.80 & 13.82 & 6.29 \\
\hline 1986 & 2827 & 14168 & 16.97 & 10.59 & 8.49 & 5.36 & 8.48 & 5.22 \\
\hline 1987 & 2551 & 11732 & 19.60 & 10.06 & 7.06 & 4.26 & 12.54 & 5.79 \\
\hline 1988 & 2127 & 15181 & 18.33 & 10.67 & 8.92 & 5.26 & 9.40 & 5.40 \\
\hline Total & 17720 & 119107 & 20.48 & 10.57 & 10.10 & 4.51 & 10.38 & 6.06 \\
\hline
\end{tabular}

rates (20.1, 15.4 and 16.7, respectively) than the other populations of India. A high twinning rate of 23.3 per 1,000 was also reported for the Muslims in Pakistan [3].

In the present study, the proportion of twins in the BMP, 0.02048, was found to be significantly higher $(Z=12.38, p \leqslant 0.01)$ than the proportion, 0.01057 , in the BHCP. A genetic similarity between the BMP of Bangladesh and the BMP and BHCP of West Bengal, India is evident from the similar gene frequencies found in a number of serum proteins and red cell enzyme system analysis [20]. The origin of the Bengalee Muslim populations of West Bengal and Bangladesh can be traced back to a single source. According to Risley [21], the Mahamadans (BMP) claim to be of distinguished foreign descent, while, in effect, they are native Indian converts recruited from the lowest caste Hindu community and who embraced Islam as a short cut to social promotion. Thus, the significant difference in twinning between the BMP and the BHCP of West Bengal may be ascribed to the prevalence of inbreeding in the former population. Traditionally, the Muslim population, as a religious group, is characterized by a marked preference for consanguineous marriages. The incidence of consanguinity in the Muslim population of West Bengal was found to be 22.2 with an inbreeding coefficient of 0.0135 [14]. A higher twinning rate was also reported for consanguineous rather than nonconsanguineous BMP couples in four villages of 24 Pargana districts in West Bengal [2]. Furthermore, that the twinning phenomenon has a direct relationship with the inbreeding status of the mother has also been indicated [12]. Inbreeding, therefore, may contribute to an increased homozygosity of recessive genes and consequently the higher twinning rate in the BMP. On the other hand, an association between increased homozygosity and inbreeding may not be necessarily identifiable in specific loci [15]. Moreover, the linear progress of homozygosity is interrupted by the adaptive process of certain enzymes $[16,17]$.

Mean family sizes of 2.6 for families without twins and 4.3 for those with twins were 
obtained in a study of over 50,000 pregnancies in 12 American hospitals [1]. Twins do tend to occur in large families and so the parents of twins are, on average, more fertile than other parents. A higher fertility level among Muslims than among Hindus in India has also been suggested [6]. In the present study, the average number of children born to women in the BMP and the BHCP were 2.58 and 2.09 , respectively. The difference is not statistically significant $(t=01.06,, p \geqslant 0.01)$, so higher fertility does not account for the increased twinning rate in BMP found in our study. We would conclude that inbreeding is, perhaps, the most likely factor responsible for the increased twinning rate in the BMP of West Bengal.

Acknowledgement: This study was supported by Major Research Project Grant No.F.3316/90 (SR-II) of New Delhi University Grants Commission.

\section{REFERENCES}

1. Allen G (1981): The twinning and fertility paradox. In Gedda L, Nance WE (eds): Twin Research 3: Twin Biology and Multiple Pregnancy. New York: Alan R. Liss, pp. 1-13.

2. Barua S (1977): Twinning rates in India. Paper presented at the Seminar on Human Variation, Calcutta (Unpublished).

3. Bulmer MG (1970): The Biology of Twinning in Man. Oxford: Clarendon Press.

4. Curtius F, Verschuer OV (1932): Die Anlagenzur Entstelung von Zwillingen und ihre Vererbung. Arch Rass u Ges Biol 26:361-387.

5. Davenport CB (1919): A strain producing multiple births. J. Hered 10:382-384.

6. Davis K (1957): Institutional patterns favouring high fertility in underdeveloped areas. In Shanon LW (ed): Underdeveloped Areas. New York: Harper \& Bros.

7. Detweiler SB (1933): Twinning in seven generations of the Bartslet family. J Hered 24:139-144.

8. Fetscher R (1928): Ein Stammbaum mit Mehrlingsgeburten . Arch f Rass Ges Biol 20:432-433.

9. Gait EA (1902): Census of India 1901, Vol. VI, Govt. of India.

10. Gedda L (1961): Twins in History and Science. Springfield, Illinois: Charles C. Thomas.

11. Gedda L, Brenci G (1965): Human monozygotic and plurizygotic multiple births: heredity and hormone action. Acta Genet Med Gemellol 14:109-131.

12. Goswami HK (1987): Twinning and inbreeding in India: the fraternal component: Acta Genet Med Gemellol 36:343-347.

13. Gruelich WW (1934): Heredity in human twinning. Am J Phys Anthrop 19:391-431.

14. Huq F (1976): Consanguinity and inbreeding among the Muslims of Murshidabad and Birbhum district of West Bengal. J Indian Anthrop Soc 11:21-25.

15. Jenkins T, Beighton P, Steinbugg AG (1985): Serogenetic studies on the inhabitants of Tristan de Cunha. Ann Hum Biol 12:363-371.

16. Johnson GB (1974): Enzyme polymorphism and metabolism. Science 184:28-37.

17. Lerner M (1954): Genetic Homeostasis. New York: John Wiley.

18. McKusick VA (1972): Human Genetics. New Delhi: Prentice-Hall of India Private Limited.

19. Nylander PPS (1969): The frequency of twinning in a rural community in Western Nigeria. Ann Hum Genet Lond 33:41-44. 
20. Papiha SS, Roberts DF, Ali SS, Islam MM (1975): Some hereditary blood factors of the Bengali Muslim of Bangladesh (Red cell enzymes, haemoglobin and serum proteins). Hum Genet 28:285-293.

21. Risley HH (1891): The Tribes and Castes of Bengal. Vol I, Govt. of India, Calcutta.

22. Roberts LW (1905): A case of quadruplets. Br Med J 11:629-630.

23. Sarkar SS (1945): The frequency of plural and multiple births in India. Trans Bose Res Inst 16:1-10.

24. Stern C (1973): Principles of Human Genetics. San Francisco: WH Freeman \& Co.

25. Wehefritz E (1925): Uber die Vererbung der Zwillingsschwangerschaft. Zeits f Konstlehre 11:554-575.

26. Weinberg W (1901): Beitrage Zur Physiologie und Pathologie der Mehrlingsgeburten beim Menschen. Arch Ges Physiol 88:346-430.

Correspondence: Prof. A.B. Das Chaudhuri, Human Genetics Laboratory, Department of Anthropology, University of Calcutta, 35 Ballygunge Circular Road, Calcutta 700019, India. 